
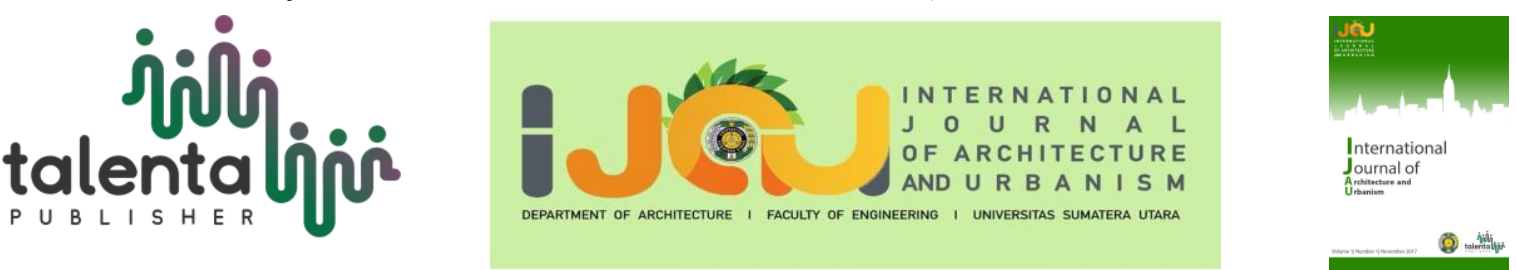

\title{
The Designing of Villa in Tourist Area Sipiso-Piso
}

\author{
Firman Eddy ${ }^{I}$, Amanda Yasmine D. Matondang ${ }^{1 *}$ \\ ${ }^{I}$ Department of Architecture, Faculty of Engineering, Universitas Sumatera Utara, Medan, Indonesia
}

\begin{abstract}
Villa is a facility lodging that is not only used for resting during leisure or recreation but also requirements for means of gathering places and deliberations (meetings) with providing room service and meeting rooms. Sipiso-Piso is the name of the famous waterfall that is in Karo's land. Sipiso-Piso Villa provided to tourists who want to stay in the Sipiso-Piso area and to feels and enjoy the view from Toba Lake and the nature of the hills and Sibuatan Mount. It has four types of villas expected to hold different quantities of tourists. This villa also to accommodate MICE activity when in works days. It has facilities support, which is a restaurant, jogging track, and park. Each type has its private pool. This villa adopted tropical architecture. Thermal comfort is the most aspect of this theme.
\end{abstract}

Keyword: MICE, Sipisio-Piso, villa

Received 1-11-2019 | Revised 10-11-2019 | Accepted 14-11-2019

\section{Introduction}

Tourism is a crucial sector of a country because it can increase its economic state. Infrastructure and facilities need to be provided in an adequate amount. Thus, this sector can develop, which will catch tourists' interest.

MICE stands for Meeting, Incentive, Convention, Exhibition. According to Kesrul (2004: 3), MICE as a tourism activity whose activities are a mix of leisure and business. One of the MICE activities is to prepare accommodation. The point of building a villa is to supporting the continuity of MICE itself. This villa is also expected to be a temporary residence for guests as well as guests who want private housing [1].

Holiday and business trips are expected by the employers to help the employees solving the problems that occur while doing the business with a clear mind. Owing to this, Sipiso-piso is the potential to support the development of MICE because it is located in a tourism area and in the hills which have mild air and beautiful scenery; thus, the businessmen can clear their minds.

\footnotetext{
*Corresponding author at: Department of Architecture, Faculty of Engineering, University of North Sumatra, Perpustakaan Street, J07 Building, Medan, 20155, Indonesia

E-mail address: amandayasmin.dmtd@gmail.com
} 
MICE tourism has a considerable multiplier effect, which can raise the economic income and drive the other sectors that are related to this tourism. These sectors are the food sector, accommodation sector, etc.

Therefore, it is crucial to design the villa for accommodation to support the activity of MICE. Because it is in a hilly area makes the land contoured so that the design of this villa follows a different contour height with several types to accommodate several different numbers of users. This design is expected to give temporary accommodation privately for the guests who want to stay at more private accommodation.

\section{Literature Review}

Villa is a temporary place to stay for holidays, located outside the fresh air areas such as in the suburbs, mountains, beaches, etc. According to Muhammad (2003), a villa is a form of building, a symbol, accommodation company or business entity that provides lodging services, intended for the general public, both those who spend the night in the villa or those who only use a few facilities that the villa has [2].

Based on several sources, it can conclude that the villa is a facility lodging that is not only used for resting during leisure or recreation but also requirements for means of gathering places and deliberations (meetings) with providing room service and meeting rooms. With this villa, you can provide benefits not only for lodging services but also for a city or a few areas.

Private Villa is a villa that functions for family resorts owned by individuals and is rarely used for commercial purposes. Private villas are usually in the form of stand-alone buildings and are not connect to other villas.

Resort Villa is a villa in the form of a resort with separate buildings like a villa. The services of star-rated villas with all the advantages of amenities can found in this type. Of course, the resort villas are built for commercial purposes to obtain profits and rentals for each villa unit. At Resort Villas usually have a landscape area, and the villas in it have a relationship with each other included in their management.

\section{Tropical Architecture}

Tropical architecture is a type of architecture that provides an answer/adaptation of building forms to the influence of tropical climates, where tropical climates have a few characteristics caused by solar heat, high humidity, rainfall, wind movements, and so on. The characteristics of the tropical humid and the impact on common problems regarding the building faced, as said by Lippsmeier, 1994:18. Is; landscape picture is rainforest areas in the lowlands, ground level: the land is usually red or brown, vegetation: dense and vary throughout the year, season: small 
seasonal differences [3]. The hottest month, hot and humid until it is wet. Coldest moon, moderate heat, and moist until wet. Cloud conditions: cloudy and foggy all year round. Precipitation: annual rainfall 500-1250 mm. During the season, no dry or little rain. During the rainy season, it varies every place. Humidity: absolute humidity(steam pressure) high enough, up to $15 \mathrm{~mm}$ during the dry season, at rainy season up to $20 \mathrm{~mm}$. Relative humidity ranges from $20-85 \%$, depending on the season. Air movement: strong wind and constant. In the jungle areas lower, faster when it rain. Usually, there are one or two main wind directions [4].

In Egan (1975: 13) state that heat loss in humans caused by convection, evaporation, and radiation, convection gives contributions around $40 \%$ of evaporation, which is about $20 \%$, solar radiation nearly equivalent to convection is around $40 \%$, and the smallest is usually low conduction. This amount of heat loss will determine someone's response to the environment around so he will able to feel comfortable or inconvenience. Comfort factor thermal is supported by temperature air, radiation, air movement, and relative humidity. These four factors, in certain combinations, will produce a certain comfort thermal [5].

The application aerodynamics architecture may help us to control thermic condition in the building to reach a comfort. Especially to a tropical rainforest climate. Aerodynamics architecture concept is the best way to explore a layout of the building to increase the airflow to bring out passive cooling, which can conserve energy. Planting the trees is a simple strategy and cheap to cooling the area. This strategy is an amplification concept of aerodynamics architecture. Sunshades and sun protection devices on openings reduce heat gain and glare, and also help in internal daylighting. Adjustable louvers can alter the direction of airflow and lighting. Asian houses have big roof overhangs to protect interior spaces from heat gain and glare. Shading materials should reflect heat and not be another source of heat. Roof insulation is a must in our warm climate. It can reduce the temperature significantly inside the house [6].

\section{Methodology}

The chosen designed location was a site located in Naga Mariah, Simalungun Regency, North Sumatera. Design analysis stage by the information and data that support both architectural and non-architectural. The data obtained are processed qualitatively by analyzing user activities, spatial requirements, spatial settings, and circulation, then the data are processed quantitatively by analyzing spatial capacity and approaches to locations and sites. These analyzes are very influential on the design, namely: Site analysis, function analysis, activity analysis, spatial analysis, and structural analysis to solving problems which including basic concept, site plan design, circulation concept, mass composition concept, plan concept, structure, and utility concept. The final stages of the development of the design idea will pour into the detail of the plan, section, and 3D impression. 


\section{$4 \quad$ Result and Discussion}

How to build the second residential building that the function is to be the new tourism place that supports MICE activity and locates on the hill with Toba lake view. With interpreting the application of a tropical architecture theme. The building is designed to give the user thermal comfort without reducing the scene to Toba Lake.

The function of this villa is to be the new tourism place that supports MICE activity and locates on the hill with the Toba lake view. The user's activity on this villa is resting, relaxing, gathering, bbq, swimming while enjoying the view of Toba Lake. So from this analysis, users need; bedroom, bathroom, living room, kitchen, swimming pool, carport, yard. And to supports MICE activity, this villa has four types that can contain a few people with different numbers.

The site location is on Naga Mariah, Pematang Simaluhut, Simalungun Regency (Figure 1). The site is close to several attractions, namely; Gundul Hill, Sipiso-Piso Waterfall, Lake Toba, etc. Because of that, the design of the villa on this site can support tourism in this area.

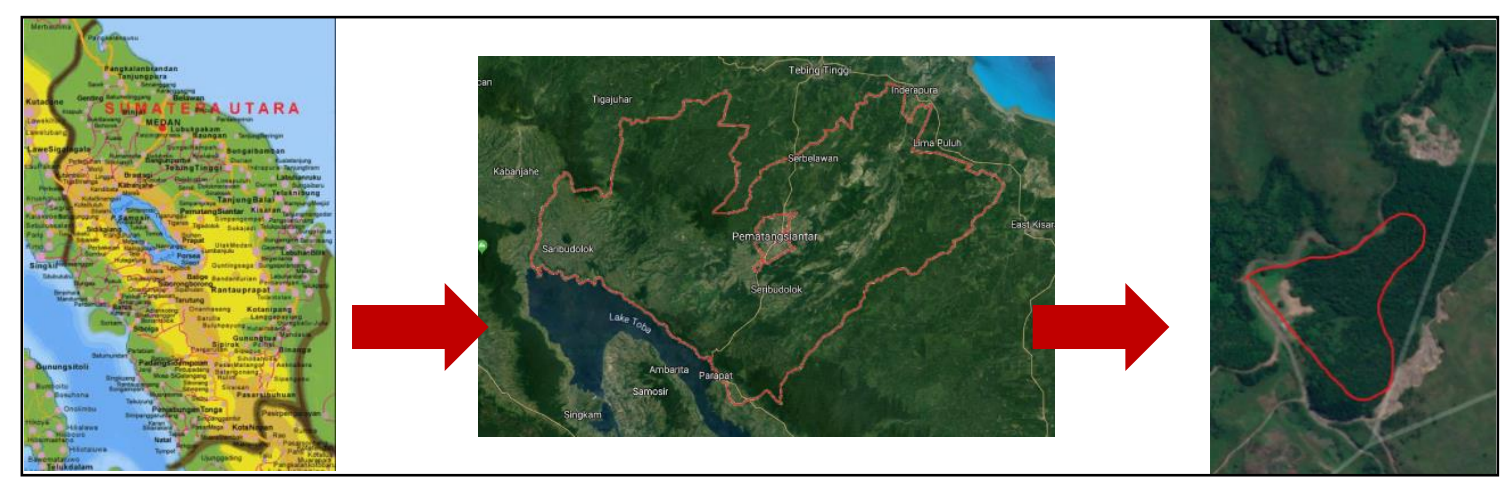

Figure 1 Location Map

There are two types of functions of this site, private and public areas (Figure 2). Private areas are villas; there are four types of villas. Public areas are placed close to the main road so the users can access to public spaces. The private spaces are placed far from the main road so that it is more private and quieter.

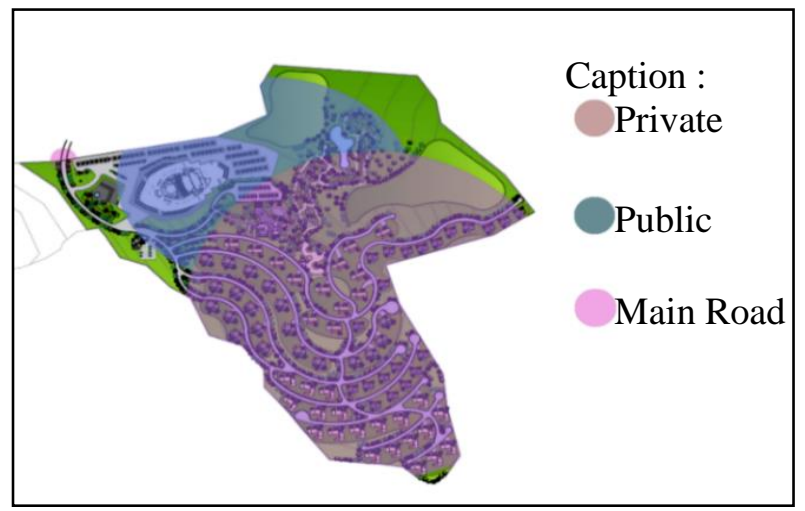

Figure 2 Zoning 
Public areas are placed close to the main road so that users immediately find public areas. The private area is far from the main road so that it is more private and quieter (far from public areas). Mass building north orientation. Placement of the building mass is based on the analysis of the view so that the building gets a scene of Toba Lake, located in the southern site. Villas type 4 with two floors, placed on the highest contours that they do not disturb the views of other villas (Figure 3). Type 3 has two floors with an entrance on the 2 nd floor. Placed on a steeper contour (Figure 4). Villas type 2 is on a flatter contour (Figure 5). Villas type 1 placed on flat land (Figure 6).

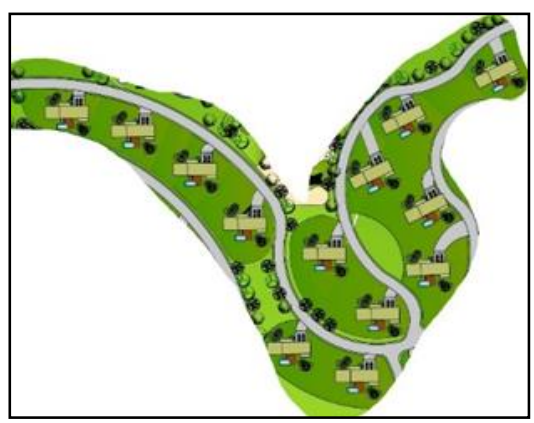

Figure 3 Villas Type 4 Site

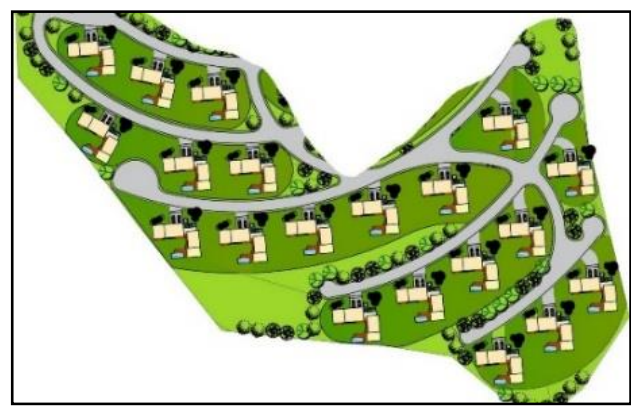

Figure 5 Villas Type 2 Site

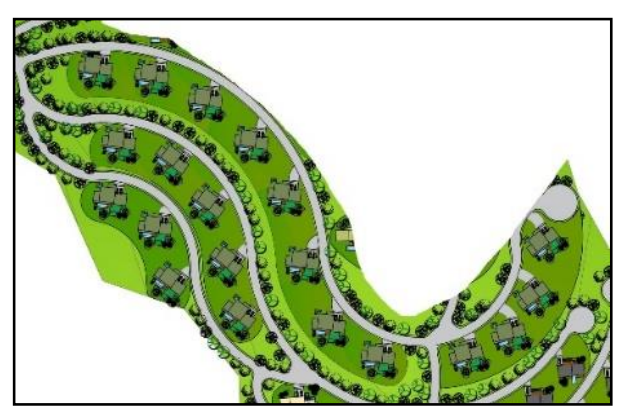

Figure 4 Villas Type 3 Site

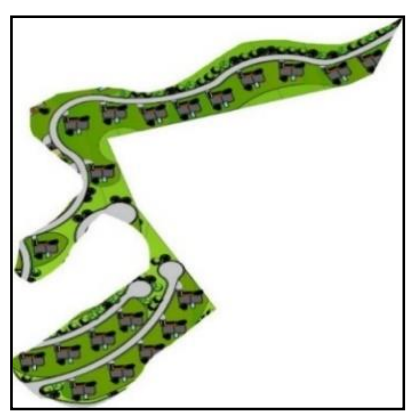

Figure 6 Villas Type 1 Site

In a one-bedroom and two-bedroom villa building, circulation considers the view outside the building, so that every room in the building has an optimal view (Figure 7). In villas 3 and 4 bedrooms, there is a vertical circulation using stairs; this building consists of 2 floors (Figure 8).

Because of consideration so that all rooms get a view overlooking Lake Toba.

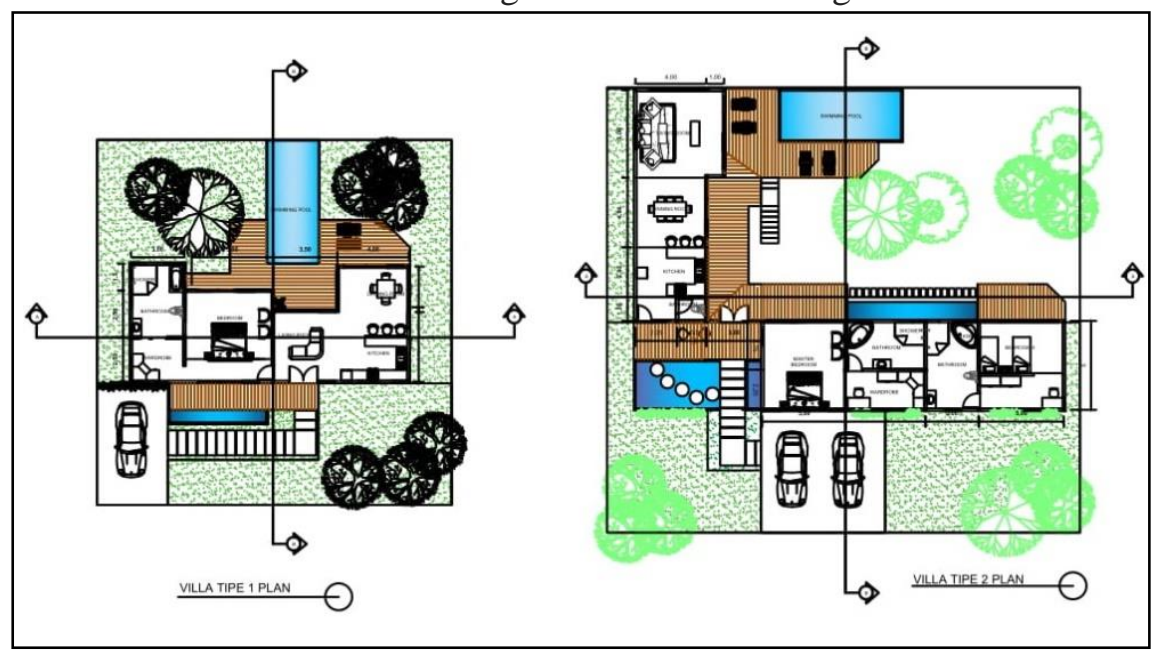

Figure 7 Villa Type 1 and 2 Plan 


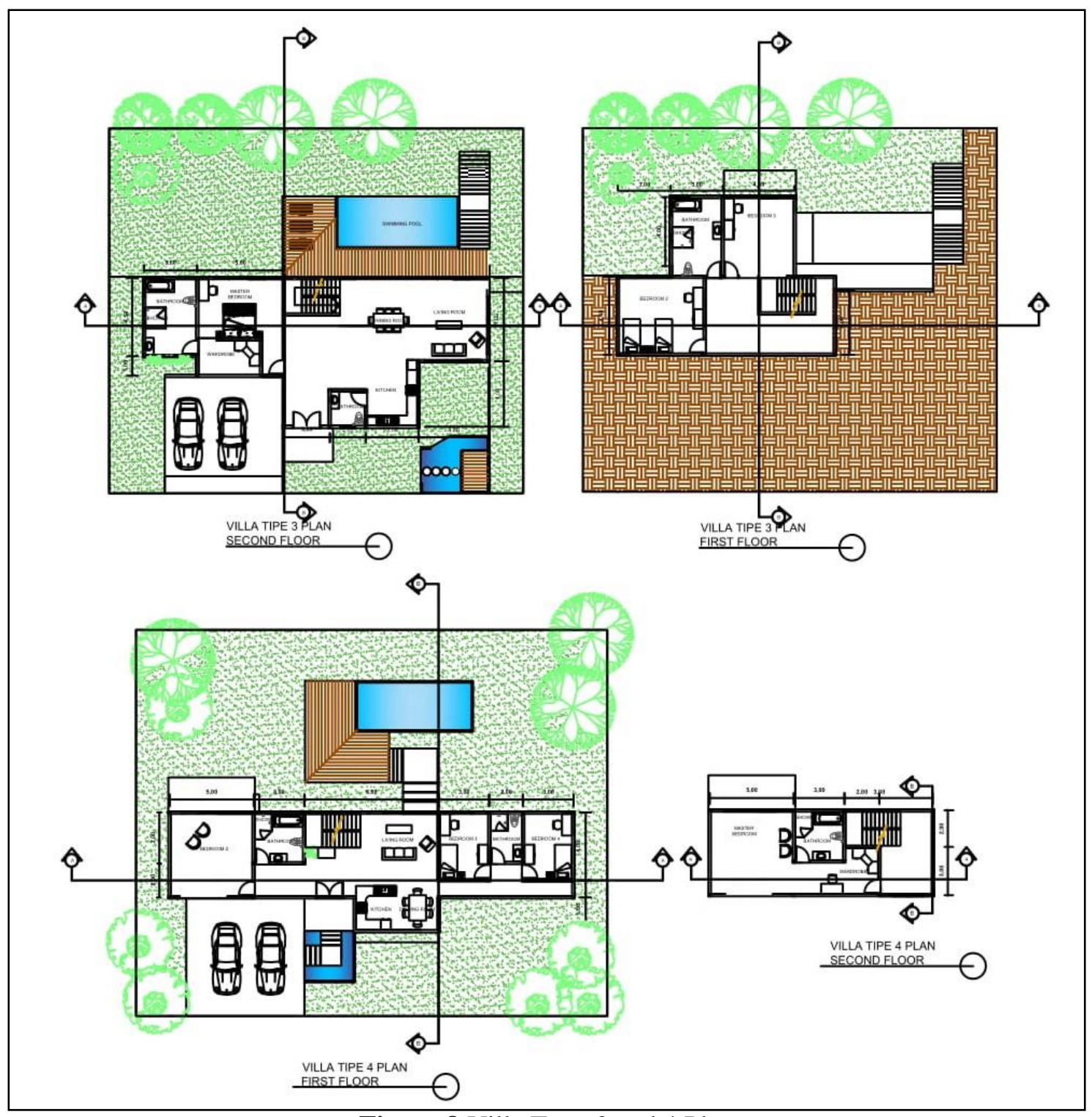

Figure 8 Villa Type 3 and 4 Plan

The only entrance placed in the northern part of the site. For public areas and reception, there is a private parking area. Pedestrian on the left and right all along on motor vehicle track. With $1 \mathrm{~m}$ on each side (Figure 9).

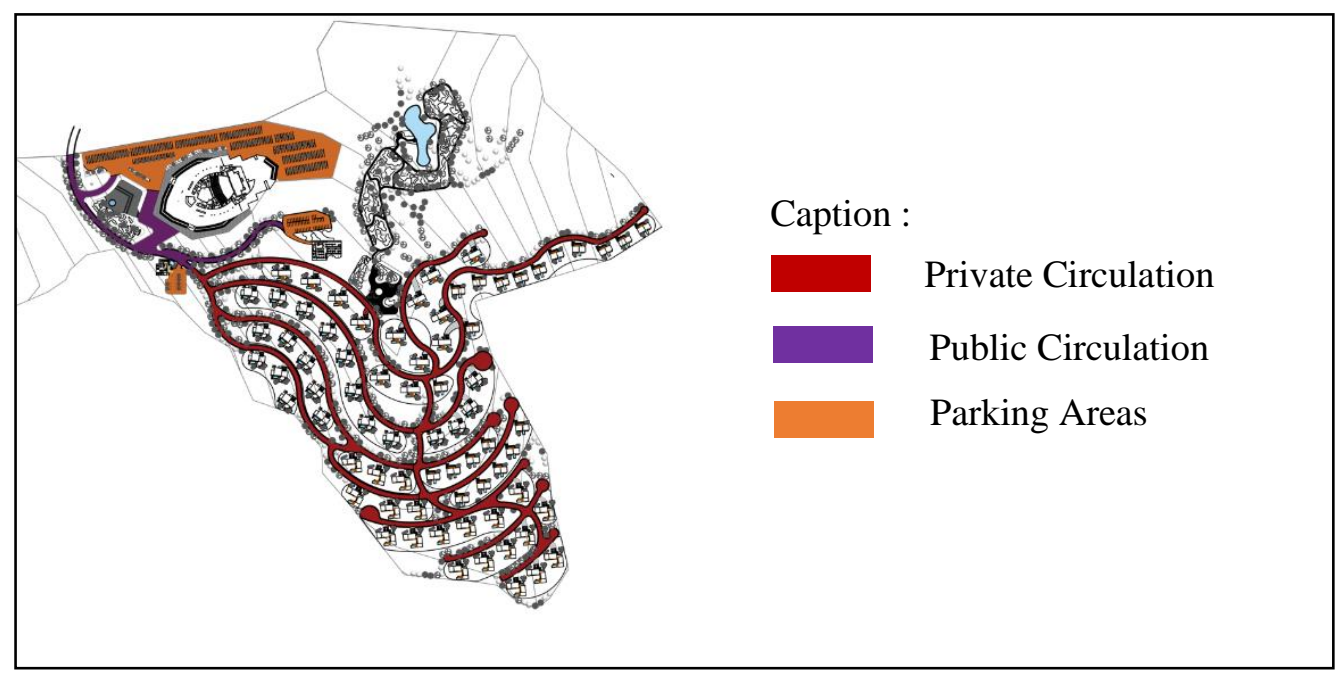

Figure 9 Circulation Motor Vehicle and Pedestrian 
Tropical architecture for thermal comfort, because of that, some aspect that applied in this concept: minimize windows from the west and east side to reduce the heat. North and south windows coated with windows film that can reduce the sunlight heat to reduce air conditioning use in summer without reducing view to Toba Lake (Figure 10).

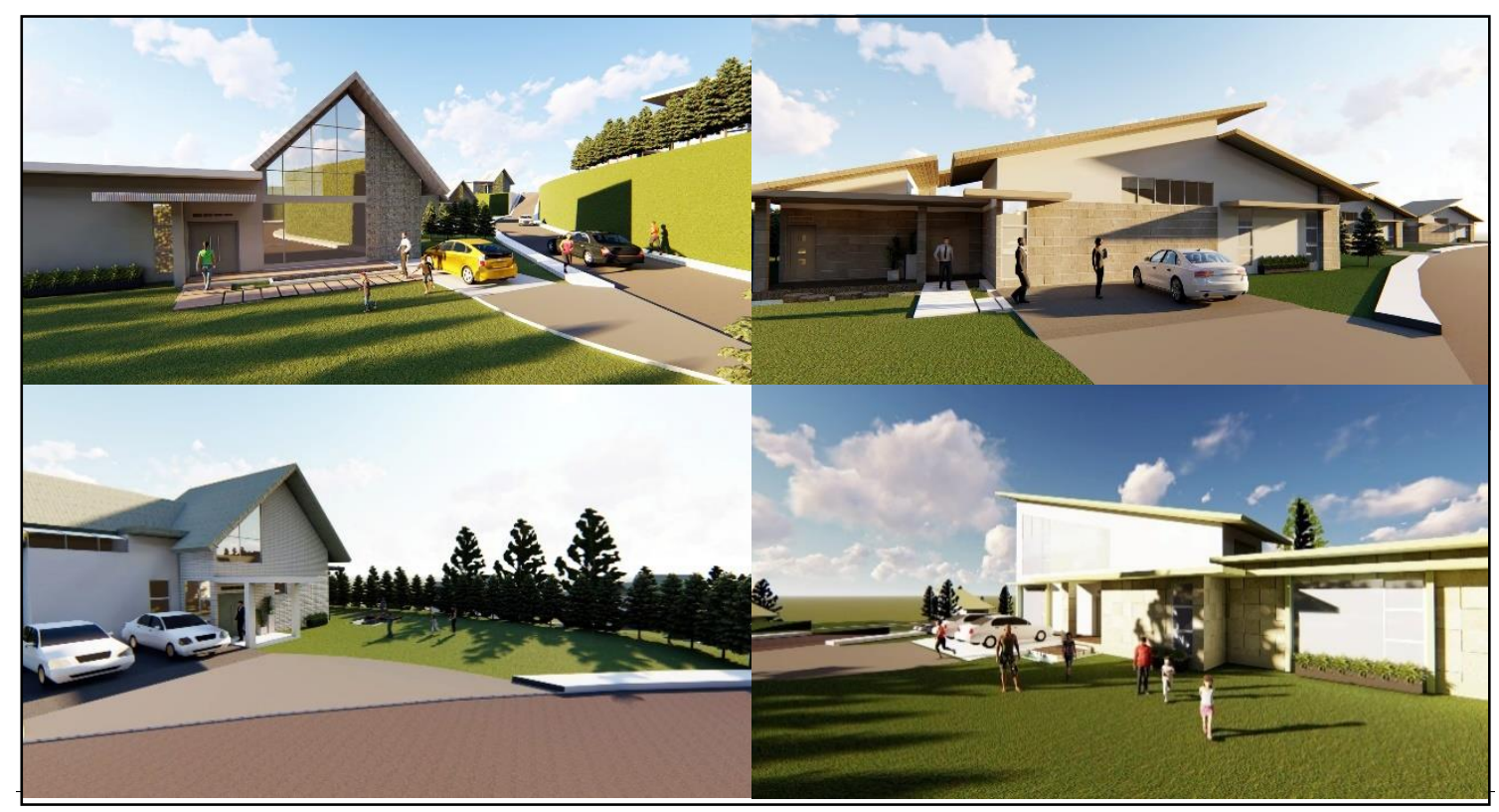

Figure 10 Villas Exterior

The air circulates through the building. The heat is milder than the fresh air, so the building uses cross ventilation so the fresh air can fulfill the building. The fresh air comes in from the ventilation-under and out from the ventilation-above (Figure 11).

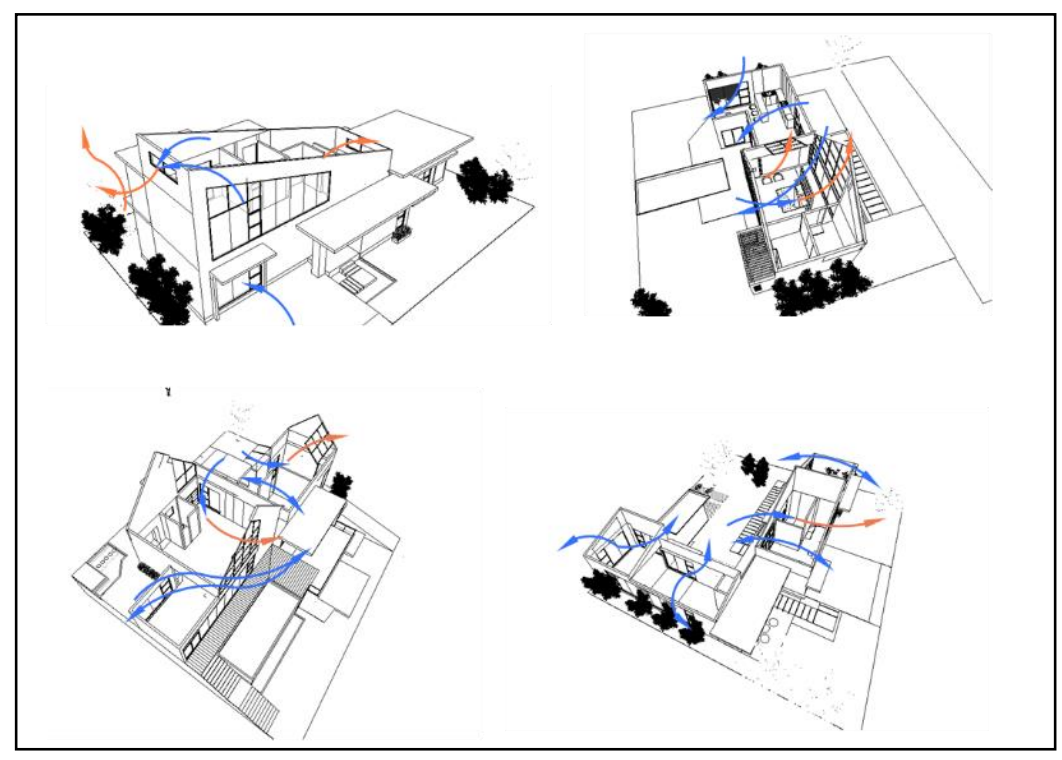

Figure 11 Air Circulation

Water elements such as a pool as facilities to reduce the airwaves around. So the water in the pool will absorb warm air and automatically the air flowing fresher (Figure 12). The building 
also has the overhang with $1,2 \mathrm{~m}$. Using overhang with $1,2 \mathrm{~m}$ can reduce the lighting level to the building. So the light that comes into the room not excessive (Figure 13).

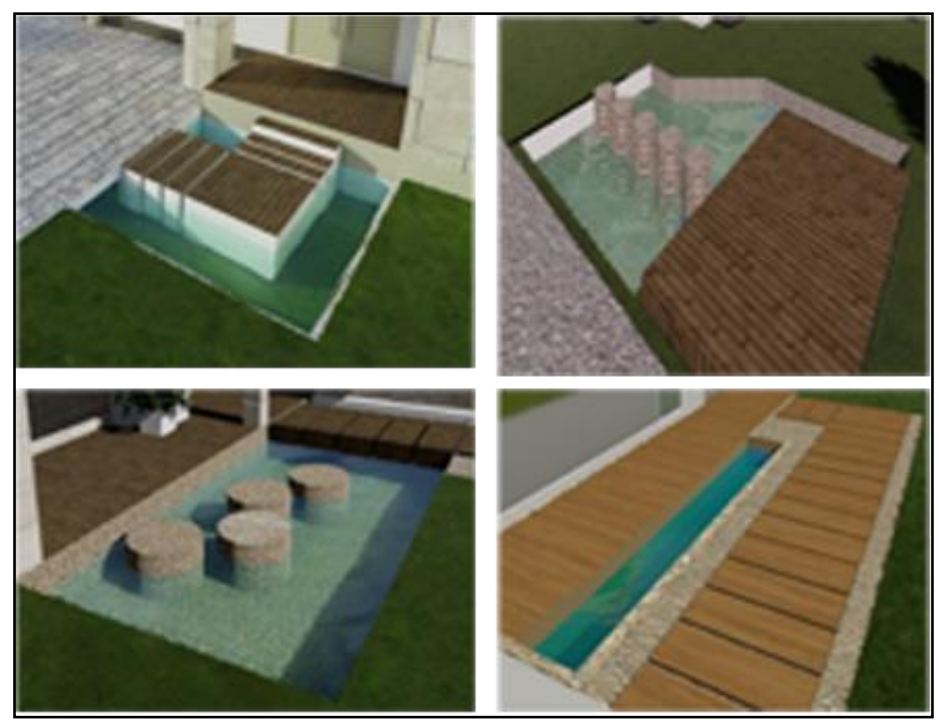

Figure 12 Water Element

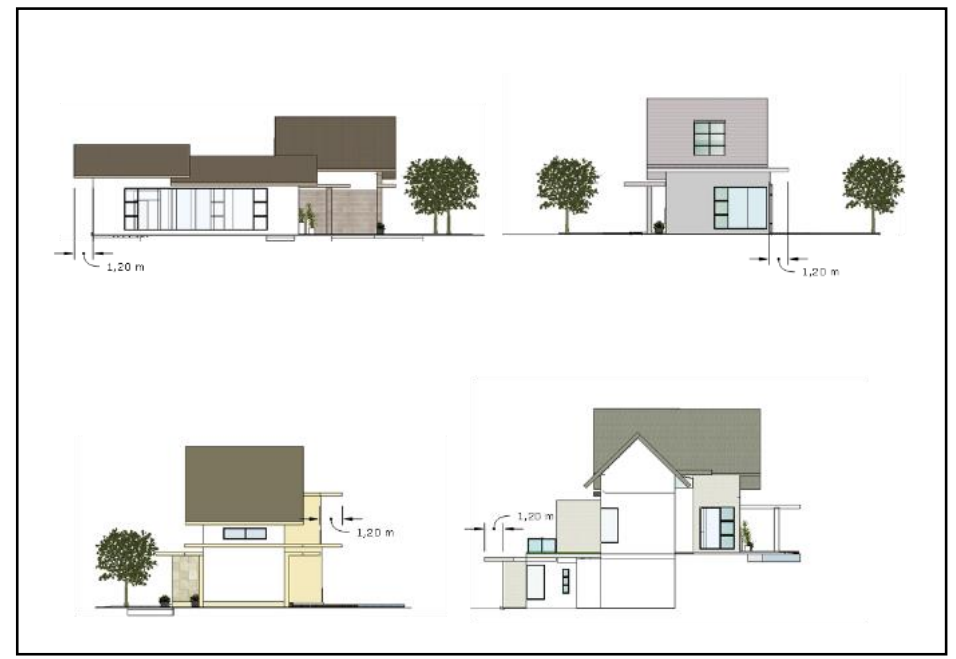

Figure 13 Overhang

The structure of this Villa design is using reinforced concrete material foundation footplate because the foundation stronger holds the load in the mountain area, which has a different state contour. For the reception, coffee shop using a grid structure. Column and beam using reinforce the concrete structure to give more strength for the building.

\section{Conclusion}

Sipiso - Piso Waterfall is one of the most tourist attractions in North Sumatra. With the beauty of the waterfall, many tourists want to come to see natural beauty. Toba lake is also a North Sumatra tourism icon. Therefore Villa was built in the Sipiso-Piso area with beautiful panoramic and fresh air with the application of tropical architecture. Because tropical architecture is suitable for use in tropical climates, and tropical architecture is an architecture that responds to the climate in the tropics (Indonesia). The concept of Tropical architecture 
prioritizes thermal comfort, therefore this villa prioritizes the user convenience, as applied to wind circulation buildings by applying cross ventilation, use window film to protect the glass, but can still expose the natural beauty of Sipiso-Piso, buffer as a fence between the villa, and also water material as environmental conditioning. This villa also provides facilities such as private swimming pools, restaurants, jogging tracks, and parks.

\section{Acknowledgment}

This research is a study of the Designing Of Villa In Tourist Area Sipiso-Piso with the application of the concept of tropical architecture that intended to give a recommendation to the government about a solution for tourist accommodation to enhance the city's tourist attraction.

\section{REFERENCES}

[1] M Kesrul, "Meeting, Incentive Trip, Conference, Exhibition," Jakarta, 2004.

[2] Bams Muhammad, "Villa Sebagai Alternatif untuk Bermusyawarah," Jakarta, 2003.

[3] G Lippsmeier, Tropenbau Building in the Tropics, 2nd edn., edited by PW Indarto. Jakarta : Erlangga, 1994.

[4] Wahyu Utami and Reza Bahrian, "Designing of Tuktuk Siadong Lakeside Resort (Tropical Architecture)," International Journal of Architecture and Urbanism, vol. 03, no. 03, pp. 351-360, 2019.

[5] M. D. Egan, Concepts in thermal comfort.: Prentice Hall, 1975.

[6] Amado de Jesus. (2011, September) Tropical architecture. [Online]. https://business.inquirer.net/19613/tropical-architecture 